\title{
A DESPROPORCIONALIDADE DA CRIMINALIZAÇÃO DO ABORTAMENTO DE FETO ANENCÉFALO: O ANACRONISMO DA LEI PENAL FRENTE À NOVA ORDEM CONSTITUCIONAL
}

\section{Caroline Köhler Teixeira'}

Resumo: Este artigo tem objetivo de acusar a desproporcionalidade das normas incriminadoras do aborto quando o feto é portador de anomalia incompatível com a vida extrauterina. Traz à baila o princípio da proporcionalidade como instrumento de verificação da inconstitucionalidade de normas. Destaca, assim, o anacronismo da legislação penal que tipifica o aborto e a desproporcionalidade da criminalização da antecipação terapêutica do parto de gravidez de feto anencéfalo. Submete as normas penais acerca do aborto ao crivo dos elementos parciais do princípio da proporcionalidade - adequação, necessidade e proporcionalidade em sentido estrito - para, ao final, concluir pela desproporcionalidade do tratamento criminalizante do aborto quando a gravidez abriga feto anencéfalo.

1 Aluna do Módulo II da Escola Superior da Magistratura do Estado de Santa Catarina (ESMESC). Advogada. Especialista em Direito Público pelo Instituto de Ensino Luis Flávio Gomes (LFG) em convênio com a Universidade do Sul de Santa Catarina (UNISUL) e pela Escola Superior da Magistratura Federal do Estado de Santa Catarina (ESMAFESC) em convênio com a Universidade do Vale do Itajaí (UNIVALI). Bacharel em Direito pela Universidade Federal de Santa Catarina (UFSC). E-mail: carolinekt@brturbo.com.br 
Palavras-chave: Aborto. Anencefalia. Colisão de direitos fundamentais. Princípio da proporcionalidade.

\section{INTRODUÇÃO}

O aborto é questão que sempre provoca muita polêmica na sociedade brasileira, dando azo a manifestações apaixonadas de diversas facções sociais, sobretudo as de nuances religiosas. Recentemente uma discussão em nível nacional de grandes proporções tomou corpo em razão do ajuizamento da Ação de Descumprimento de Preceito Fundamental 54 (BRASIL, 2010), que questiona a constitucionalidade dos tipos penais que incriminam o aborto ao não excetuarem a hipótese de ser o produto da concepção portador de anencefalia.

No tramitar dessa medida de controle de constitucionalidade concentrado, o Supremo Tribunal Federal permitiu amplo debate acerca da questão, por instituições pertinentes ao tema e de envergadura nacional, as quais trouxeram relevantes argumentos que certamente contribuirão com o acerto da decisão que será tomada pela Corte Suprema.

Nessa esteira, aqui se intenta realizar o exame da constitucionalidade material das normas que incriminam o abortamento de feto anencéfalo (ou antecipação terapêutica do parto), mediante um juízo de proporcionalidade calcado na ponderação entre os interesses, bens e direitos constitucionais envolvidos - como a vida do nascituro, sua viabilidade, e o interesse estatal em tutelá-la, de um lado, e, de outro, a privacidade, a liberdade, a autodeterminação, a saúde e os direitos reprodutivos da gestante.

Ressalte-se que não se pretende verificar o acerto de premissas alheias à Ciência do Direito. Ao contrário, almeja-se apreender a questão jurídica que envolve o tema, a qual deve ser explorada, desde o início, à luz da própria Constituição. Isto porque o papel do Direito é valorar a realidade posta - e não estabelecer como ela efetivamente é ou deixa de ser, dado que 
é ciência do dever ser - e, a partir disso, estabelecer a extensão da tutela jurídica que ela é merecedora, trazendo segurança jurídica às pessoas.

Destarte, a primeira abordagem se voltará a delinear a aplicação do princípio da proporcionalidade como parâmetro para verificação da constitucionalidade material de normas. Ao depois, analisar-se-á a legislação penal que criminaliza o aborto, ressaltando-se seu anacronismo. Por fim, restará demonstrada a desproporcionalidade da proibição criminal do abortamento de feto anencéfalo, submetendo-a ao crivo do princípio da proporcionalidade e seus elementos parciais - adequação, necessidade e proporcionalidade em sentido estrito.

\section{PRINCÍPIO DA PROPORCIONALIDADE}

O postulado da proporcionalidade das leis tem espaço, sobretudo, quando direitos fundamentais e bens constitucionalmente albergados entram em rota de colisão, conforme a lição de Canotilho (1999, p. 266):

O campo da aplicação mais importante do princípio da proporcionalidade é o da restrição de direitos, liberdades e garantias por actos dos poderes públicos. No entanto, o domínio lógico de aplicação do princípio da proporcionalidade estende-se aos conflitos de bens jurídicos de qualquer espécie.

Com efeito, ele assume inegável importância na realidade jurídica brasileira, mormente em razão do vasto catálogo de direitos fundamentais inserto na Carta Política Brasileira. Isso porque a coexistência de tantos direitos de tal estirpe, que são exercidos por uma pluralidade de sujeitos de direito, por vezes dá ensejo a uma situação em que referidos direitos entram em rota de colisão, reclamando uma solução de harmonização prática.

Dada a natureza principiológica, que denota sentido materialmente aberto e caráter polissêmico das normas consti- 
tucionais, e, por conseqüência, dos direitos fundamentais que são por ela albergados, o embate entre direitos de tal categoria reclama uma técnica diferenciada de solução, a fim de que não se aniquile nenhum dos interesses em contraposição (STEINMETZ, 2001, p. 63).

É inegável que os direitos fundamentais desfrutam de um núcleo de proteção mínima, o qual não pode ser de maneira alguma sacrificado. Respeitado o núcleo mínimo de cada direito fundamental, é justamente a coexistência de tais direitos, à luz das situações concretas, que lhes dá conformação jurídiconormativa (SARLET, 2009, p. 129).

Destarte, a harmonização prática dos direitos fundamentais invoca a aplicação do princípio da proporcionalidade, de modo que não se admite a exclusão de um direito fundamental pelo simples fato de contrastar com outro ou outros da mesma espécie ou com algum bem constitucionalmente protegido.

Não obstante, sua utilidade não se exaure no desempenho desse mister, como foi brilhantemente explanado acima pelo mestre português. $\mathrm{O}$ postulado da proporcionalidade também vem sendo amplamente utilizado como relevante instrumento que permite a verificação da constitucionalidade material de leis restritivas de direitos fundamentais.

A especificidade deste controle de constitucionalidade, calcado no princípio da proporcionalidade, recai sobre o fato de não se bastar com o mero contraste lógico direto entre as normas escritas e a Constituição. Ele vai além, ao averiguar a ocorrência de excesso de poder do legislador - sem, contudo, adentrar no mérito legislativo - com o intuito de se certificar que as leis se coadunam com os fins constitucionalmente previstos.

Como instrumento viabilizador da verificação da constitucionalidade material das normas jurídicas, Barros (2003, p. 215) afirma que a proporcionalidade, em nosso ordenamento jurídico, assume a natureza de princípio constitucional implícito, pois "deriva da força normativa dos direitos fundamentais, 
garantias materiais objetivas do Estado de Direito. É haurido principalmente da conjugação dos art. $1 .^{\circ}$ e $2 .^{\circ} ; 60, \S 4 .^{\circ}$, IV. Nesse sentido, complementa o princípio da reserva de lei, a ele incorporando-se, de modo a converter-se no princípio da reserva legal proporcional".

Por sua vez, Guerra Filho (1995, p. 58), alça-o à categoria de garantia fundamental, atribuindo-lhe, ainda, o status de verdadeira norma fundamental concretizadora do nosso ordenamento jurídico-constitucional de feições neopositivistas:

Ele, à diferença dos princípios que se situam em seu mesmo nível de mais alta abstração, não é tãosomente formal, pois se revela em sua plenitude apenas no momento em que se há de decidir, concretamente, sobre a constitucionalidade ou “justiça” - de alguma situação jurídica. (...) É por isso que em seguida, e para encerrar, vamos delineálo como "norma fundamental concretizadora", em contraste com a "Norma Hipotética Fundamental" da Teoria Pura do Direito, mostrando como ele aponta para um modelo do ordenamento jurídico diverso daquele dessa doutrina, arquitetonicamente definido como piramidal.

A proporcionalidade, portanto, é amplamente reconhecida como princípio conformador da nossa ordem constitucional. Porém, impende ressaltar que, em razão de não estar expressamente prevista na nossa Constituição, a dogmática ao redor de sua aplicação prática por vezes lhe atribui diferentes bases normativas.

Esses fundamentos normativos que são extraídos de diversos preceitos constitucionais não raro se complementam na justificação jurídico-constitucional da proporcionalidade como princípio implícito.

O Tribunal Constitucional Alemão, responsável pela migração do princípio da proporcionalidade da seara administrativa para o âmbito constitucional, ao alçá-lo ao patamar 
de princípio norteador de todo o sistema jurídico, justifica-o dizendo ser dedutível da própria ideia de Estado de Direito. $\mathrm{O}$ procedimento lógico daquela corte baseia-se no fato de aceitar um duplo sentido do princípio da proporcionalidade - um formal e outro material. Este representaria a noção de justiça, que é ínsita ao princípio do Estado de Direito. Assim, a justiça se concretizaria como aspecto material do princípio da proporcionalidade, baseado no Estado de Direito (STEINMETZ, 2001, p. 159-160).

Conjugada com a ideia de dignidade da pessoa humana, a proteção ao núcleo mínimo dos direitos fundamentais também é concebida como a razão de ser do princípio da proporcionalidade. Dada a intangibilidade de um núcleo mínimo dos direitos fundamentais, há uma cláusula implícita de garantia a esses direitos, que é o princípio da proporcionalidade. Este entraria em cena para impedir restrições legislativas (e até mesmo qualquer intervenção estatal) ao núcleo de cada direito fundamental, que deve ser preservado sob pena de se sacrificar o próprio direito (GUERRA FILHO, 1995, p. 58).

Gilmar Mendes (2009, p. 361-362) assinala que desde os primeiros sinais de manejo, pelo Supremo Tribunal Federal, do princípio discutido, o fundamento a que se recorria era de cláusula implícita dos direitos fundamentais. Mas com a Constituição de 1988, ocorreu nítida virada quanto a essa fundamentação. O princípio do devido processo legal (art. 5, LIV, da Constituição da República Federativa do Brasil de 1988), no seu viés substantivo, passou a dar guarida ao princípio da proporcionalidade como postulado constitucional autônomo.

Barroso (1996, p. 160-161) aduz que foi essa versão substantiva do devido processo legal que possibilitou o maior controle do mérito dos atos do Poder Público pelo Judiciário, vindo a se tornar importante mecanismo de defesa dos direitos fundamentais, ao viabilizar a averiguação da razoabilidade e da racionalidade dos atos estatais que restrinjam tais direitos. 
Enfim, Steinmetz (2001, p. 171) propõe, escorado em Alexy, base jusfundamental: "partindo da premissa de que os direitos fundamentais têm natureza principial, é possível afirmar, também, que as máximas da proporcionalidade derivam das normas-princípios de direitos fundamentais, ou seja, dos direitos fundamentais enquanto princípio".

Não obstante todos os argumentos até aqui expostos, postura mais condizente com a unidade com que deve ser interpretada a Constituição é atribuir base normativo-constitucional plural ao princípio da proporcionalidade (BARROS, 2003, p. 99-100):

A lei tem um claro significado material - não meramente formal - e, quando cuidar de restringir direitos fundamentais, para harmonizar os diversos interesses concorrentes, deve poder ter sua ratio essendi testada, ou seja, deve entrar no âmbito do seu controle o problema de se saber se é realmente adequada para conseguir o objetivo em questão. Sob este enfoque, é deveras claro que o princípio da proporcionalidade decorre do Estado de Direito, ou do Estado Democrático de Direito, ou da ideia mesma de direitos fundamentais.

Assim, são múltiplas as bases do princípio da proporcionalidade, todas aptas a viabilizar sua adoção. Independente da que se adote, importa não negar aplicação ao princípio só pelo fato de, entre nós, não estar textualmente gravado na Constituição, visto ser um relevante instrumento de salvaguarda dos direitos fundamentais, não permitindo que sejam excessivamente restringidos, notadamente pelo arbítrio do legislador.

Assentadas as premissas iniciais que viabilizam a compreensão do princípio da proporcionalidade, cumpre explanar sobre os elementos parciais que o compõem, já que é pela verificação da obediência ao teor destes que é possível dizer se uma lei restritiva a direito fundamental é ou não substancialmente constitucional. 
Assim, para se proceder à averiguação da constitucionalidade material das leis restritivas de direitos fundamentais, é mister realizar um juízo de ponderação de uma medida que acarrete o confronto entre direitos fundamentais, princípios constitucionais ou ainda bens constitucionalmente albergados, adotando-se o critério trifásico do princípio da proporcionalidade (em sentido amplo), o qual se desmembra nos seguintes subprincípios: adequação, necessidade e proporcionalidade em sentido estrito (ARAÚJJ, 2009, p. 356).

Em primeiro lugar, o exame de proporcionalidade deve recair sobre a adequação do meio eleito para o alcance do fim proposto. Para Canotilho (1999, p. 264), a adequação é uma "exigência de conformidade", que "pressupõe a investigação e a prova de que o acto do poder público é apto para e conforme os fins justificativos da sua adopção”.

Não se trata de indicar se o meio eleito pelo legislador é o mais ou menos apto a alcançar o fim por ele colimado. A análise que deve ser feita assume um viés negativo, segundo o qual "uma medida é não-idônea se o for completamente. (...) Nesse sentido, o juízo de adequação nada diz sobre qual dos meios idôneos deve prevalecer, pois não diz qual é o mais ou menos eficaz. Apenas diz se um determinado meio é ou não idôneo, útil, apto, apropriado" (STEINMETZ, 2001, 149-150).

Ressalte-se que na seara da adequação, não há mesurar o grau de eficácia dos meios considerados aptos à consecução da finalidade pretendida. Esta questão paira no campo da necessidade (BARROS, 2003, p. 78). Nesta seara, exige-se que dentre todos os meios que são igualmente aptos a produzir o resultado pretendido, somente aquele que denota inequívoca necessidade e que afeta o bem constitucional de maneira menos gravosa poderá ser eleito (STEINMETZ, 2001, 150-151).

Deste modo, diz-se que a necessidade tem como seu pressuposto a adequação, pois só seriam efetivamente necessárias aquelas medidas aptas e idôneas a alcançar a finalidade almejada (BARROS, 2003, p. 83). Em outros dizeres, Mendes (2009, 
p. 361-366) esclarece que "na prática, adequação e necessidade não têm o mesmo peso ou relevância no juízo de ponderação. Assim, apenas o que é adequado pode ser necessário, mas o que é necessário não pode ser inadequado".

Ainda importa mencionar que o subprincípio da necessidade comporta quatro componentes: a exigibilidade material, segundo a qual o meio deve ser o mais contido possível em se tratando de limitar direitos fundamentais; a exigibilidade espacial, que "aponta para a necessidade de limitar o âmbito da intervenção"; a exigibilidade temporal, a qual implica na necessidade em se delimitar o mais precisamente possível no tempo a medida restritiva; e, por fim, a exigibilidade pessoal, que consiste no imperativo de "que a medida se deve limitar à pessoa ou pessoas cujos interesses devem ser sacrificados". Tudo isso se justifica na premissa de que o cidadão tem direito à menor desvantagem possível, de sofrer o mínimo possível de restrição aos seus direitos fundamentais, e só quando isso seja absolutamente necessário (CANOTILHO, 1999, p. 264-265).

Restando positivos os exames de adequação e necessidade, urge avaliar a proporcionalidade em sentido estrito. O subprincípio em pauta exige que se efetue um juízo de racionalidade, de justa medida entre os meios e fins utilizados à luz dos bens constitucionais e direitos fundamentais relacionados (STEINMETZ, 2001, 152).

Barroso (1996, p. 168) explica se tratar "de uma verificação da relação custo-benefício da medida, isto é, da ponderação entre os danos causados e os resultados a serem obtidos. Seus dizeres são complementados por Willis Santiago Guerra Filho (1995, p. 59), ao alertar que através da proporcionalidade stricto sensu, almeja-se que "não se fira o conteúdo essencial (Wesensgehalt) de direito fundamental, com o desrespeito intolerável do valor/princípio que o define: a dignidade humana".

Enfim, intenta-se preservar, na etapa de ponderação estritamente proporcional, o equilíbrio entre valores e bens 
(BARROS, 2003, p. 85), pois é perfeitamente possível que, a despeito da comprovada necessidade da medida, identifiquemse situações que revelem "um desequilíbrio na relação meiofim, (...) porque não está em causa a existência de outra medida menos lesiva, mas, sim, a precedência de um bem ou interesse sobre outro".

Em síntese, portanto, será proporcional a medida legislativa que restringir direito fundamental, desde que seja não só adequada, mas absolutamente necessária a atingir o objetivo por ela colimado, de modo a adotar o meio menos gravoso possível ao alcance dos fins visados e, por fim, desde que o benefício por ela trazido seja maior ou igual ao ônus que será imposto, ou seja, que não seja exigível o sacrifício de determinado bem para a salvaguarda de outro.

\section{A CRIMINALIZAÇÃO DO ABORTO NO BRASIL}

O diploma normativo que trata de maneira mais aguda da interrupção da gravidez é o Código Penal (BRASIL, 1940) que, em seus artigos 124 a 128, próibe a prática do aborto, exceto nos casos de perigo para a vida da gestante (aborto necessário) ou de gravidez resultante de estupro (aborto sentimental).

Efetivamente, uma interpretação meramente textual poderia levar a crer que o sistema jurídico brasileiro incrimina a prática de todo aborto provocado, a não ser que se enquadre nas causas justificantes já expostas. Nesse contexto, num primeiro momento, a interrupção da gravidez de feto anencéfalo seria uma conduta tipificada e vedada pelo nosso sistema normativo-punitivo.

Inclusive pelo aspecto de subsidiariedade da legislação penal, que tutela os bens mais caros à sociedade (ultima ratio), protegendo-os das mais severas agressões, poder-se-ia concluir que o legislador brasileiro efetivamente optou pela proibição do aborto, tolerando apenas as exceções legais mencionadas.

Porém, a partir do advento da chamada Constituição Cidadã, é certo que todas as normas jurídicas infraconstitucio- 
nais devem ser lidas e interpretadas em clara consonância com a própria carta política, contribuindo com a unidade do sistema jurídico brasileiro.

Destarte, antes de verificar a compatibilidade dos dispositivos penais com o texto constitucional, urge tecer algumas sucintas, porém oportunas, considerações sobre a criminalização do aborto pelo diploma penal brasileiro, atentando-se ao contexto no qual foi emanada a regra incriminadora da prática de aborto ainda vigente, carente de reforma e reinterpretação à luz dos preceitos constitucionais atuais.

$\mathrm{O}$ aborto, em síntese, consiste na interrupção da gravidez com a morte do produto da concepção (DELMANTO, 2002, p. 268), sendo indiferente o estágio gestacional - seja ovo (até três semanas de gestação), embrião (de três semanas a três meses) ou feto (após três meses) (NORONHA, 1998, p. 54).

Para que a conduta provocadora do aborto se subsuma a um dos tipos penais atinentes à criminalização da interrupção da gravidez não basta a mera expulsão prematura do produto da concepção, uma vez que este pode vir a sobreviver fora do útero materno. Só com a morte do feto se dá a consumação do delito (BITENCOURT, 2008, p. 135).

De outro lado, Prado adverte que a expulsão do feto também não é conditio sine qua non para a configuração do delito em pauta. E arremata (2008, p. 107):

Não será bastante também a morte do feto, se não resultar esta dos atos praticados ou dos meios utilizados para a interrupção da gravidez ou da própria imaturidade do feto, que não sobrevive à expulsão prematura provocada por aqueles atos ou meios. O aborto consiste, portanto, na morte dada ao nascituro intra uterum ou pela provocação de sua expulsão.

Não há unanimidade na doutrina acerca do termo inicial da gravidez e, em conseqüência, nem a partir de que momento, posterior à concepção, há possibilidade de se praticar o crime de 
aborto. Há quem afirme que a tutela do tipo penal se dá desde a concepção. Assim, juridicamente, a gravidez compreenderia o tempo entre a fecundação e o início do parto (NORONHA, 1998, p. 135).

De outra banda, recentemente tem-se sustentado que o termo inicial da gravidez, juridicamente falando, para fins de configuração do crime de aborto, é a nidação, ou seja, a fixação do óvulo fecundado no útero (DELMANTO, 2002, p. 107).

Nesse viés, explica Mirabete (1991, p. 76-77):

Segundo a doutrina, a vida intra-uterina se inicia com a fecundação ou constituição do ovo, ou seja, a concepção. Já se tem apontado, porém, como início da gravidez, a implantação do óvulo do útero materno (nidação). Considerando que é permitida no País a venda do DIU e de pílulas anticoncepcionais cujo efeito é acelerar a passagem do ovo pela trompa, de modo que atinja ele o útero sem condições de implantar-se, ou transformar o endométrio para criar nele condições adversas à implantação do óvulo, forçoso é concluir-se que se deve aceitar a segunda posição, tendo em vista a lei penal. Caso contrário, dever-se-á incriminar como aborto o resultado da ação das pílulas e dos dispositivos intra-uterinos que atuam após a fecundação.

Quanto ao termo final da gravidez, juridicamente falando, é o início do parto, que se caracteriza "pelas contrações da dilatação (parto normal) ou com o início dos procedimentos cirúrgicos (v.g., cesariana)" (PRADO, 2008, p. 108). Portanto, iniciado o parto, não há falar em aborto, mas em homicídio, a não ser que se vislumbre a presença das circunstâncias elementares especiais do infanticídio (BITENCOURT, 2008, p. 135).

O aborto é tipo penal alocado no capítulo "Dos Crimes Contra a Vida", inserto no Título "Dos Crimes Contra a Pessoa", o que faz crer que referida proibição penal objetiva resguardar a vida e também a integridade física das pessoas (NORONHA, 1998, p. 54). 
O crime de aborto, especificamente, intentaria resguardar a vida intrauterina, desde a concepção ou a nidação (dependendo da corrente que se adote) até o início do parto. Ressaltese que nos casos em que o aborto é provocado sem o consentimento da gestante, sua integridade corporal é também tutelada (MIRABETE, 1991, p. 76).

Alerta Bitencourt (2008, p. 134) que o bem jurídico protegido pelo crime de aborto é a vida do ser humano no seu estágio de formação, ainda que, a rigor, não se configure em um crime contra a pessoa. Isto porque, segundo o referido autor, “o produto da concepção - feto ou embrião - não é pessoa, embora tampouco seja mera esperança de vida ou simples parte do organismo materno, como alguns doutrinadores sustentam, pois tem vida própria e recebe tratamento autônomo da ordem jurídica”.

Nesse viés, Prado (2008, p. 105) aduz que a vida é um direito inviolável, constitucionalmente assegurado e a todos conferido, assinalando que "o conceito de vida, para que possa ser compreendido em sua plenitude, abarca não somente a vida humana independente, mas também a vida humana dependente (intra-uterina)".

No entanto, cumpre ressaltar que há vozes eminentes em sentido inverso, que afirmam que apenas a vida viável é digna de tutela penal e constitucional. Assim, o feto portador de anencefalia, dada a sua inconteste inviabilidade de sobrevivência, não pode ser alçado à condição de pessoa e, portanto, não é merecedor da proteção estatal, restando inconstitucional a criminalização da prática que vise ao seu abortamento.

Nesse sentido, são as palavras de Souza Nucci (2007, p. 628):

Preferimos acreditar que a lei penal, ao punir o aborto, busca proteger a vida humana, porém a vida útil e viável, não exigindo que a mãe carregue em seu ventre por nove meses um feto que, logo ao nascer, dure algumas horas e finde a sua exis- 
tência efêmera, por total impossibilidade de sobrevivência na medida em que não possui a abóboda craniana, algo vital para a continuidade da vida fora do útero. $O$ anencéfalo não é protegido pelo direito penal, que se volta à viabilidade do feto e não simplesmente à sua existência física.

Dobrowolski não destoa, ao afirmar que o produto da concepção que seja desprovido de cérebro, dada sua inviabilidade, não pode assumir a condição de pessoa (2006, p. 63):

O feto anencéfalo, porém, é inviável e só possui existência enquanto ligado à mãe, sendo absolutamente insensível, por ausência de cérebro. Descabe considerá-lo como dotado de interesses próprios, pois não tem consciência e nunca assumirá a condição de pessoa. De afastar, por essa mesma razão, se esteja na presença de situação fática em que se deva preservar a vida em si mesma. Quanto a esse aspecto, a permissão legal para a interrupção da gravidez resultante de estupro significa que o ordenamento pátrio não adotou a ideia de que toda possibilidade vital merece ser assegurada.

Enfim, além da discussão acerca do merecimento da tutela da vida intrauterina, conforme seja ou não viável, outro argumento que pode ser trazido à baila é o fato de que a gravidez justifica-se na reprodução humana. Assim, a ausência de cérebro afetaria tão intensamente as características físicas do feto, a ponto de que sua sobrevivência, quando lograsse nascer, estaria limitada a poucos dias de vida (CERNICCHIARO, 2004, p. 27).

Desde a edição do Código Penal, em 1940, já são idos aproximadamente setenta anos e, neste lapso temporal, os valores fundantes da sociedade brasileira, temperados pela redemocratização do país, foram reformatados, dando-se especial tratamento aos direitos fundamentais. Estes foram insertos em extenso rol, o qual está em constante construção ante a possibilidade expressa de reconhecimento de novos direitos (art. $5^{\circ}, \S 2^{\circ}$, da Constituição da República Federativa do Brasil, de 1988). 
Ressalta Sarmento (2007, p. 5) que "a revisão da legislação sobre aborto, elaborada sem qualquer atenção em relação aos direitos humanos básicos da mulher, muito mais do que uma mera opção política do legislador, torna-se um verdadeiro imperativo constitucional".

Muitos argumentos, que inclusive tangem à criminalização do aborto, corroboram com a constatação de atraso da lei penal para corresponder aos atuais anseios sociais. Ora, é fato que, à época da entrada em vigor do Código Penal, o legislador não podia vislumbrar a situação como hoje se apresenta, com avançados recursos tecnológicos que permitem delimitar a viabilidade fetal com maior confiabilidade.

Portanto, não incluiu nas causas especiais de exclusão de ilicitude a situação em que o produto da concepção não ostenta viabilidade por padecer de anencefalia, estando irreversivelmente fadado à morte prematura. Ademais, segundo assinala Wambier (2004, p. 26), na gestação de feto anencéfalo já está embutida a própria ideia de aborto.

Outra questão relevante gira em torno da razão que autoriza o aborto em caso de estupro. Se a vida do feto merece tutela igual à de uma pessoa nascida, como conciliar essa premissa com a excludente de gestação resultante de crime sexual (a não ser quando resultar perigo para a vida da gestante)? Pode a honra da mulher (e de seu marido) ser tão valorosamente considerada pela sociedade a ponto de se negar o direito à vida a um feto?

Na exposição de motivos do Código Penal assim justificouse a gravidez resultante de estupro: "militam em favor da exceção razões de ordem social e individual, a que o legislador não pode deixar de atender" (grifei).

Se optou o legislador pela honra da mulher em detrimento da vida de um nascituro (viável ou não), não há porque não se excetuar também o caso de gravidez de feto anencéfalo, a fim de se tutelar, por razões de ordem individual, a integridade psíquica da mulher que carrega em seu ventre um concepto inviável, situação que lhe traz imensurável sofrimento. 
Ora, se à época da edição da legislação penal o legislador houve por bem delimitar duas causas especiais de exclusão da ilicitude (gravidez resultante de estupro ou que acarrete risco de vida à gestante) por razões de ordem social e individual, é certo que hoje, pelo mesmo motivo, seguindo a mens legislatoris, se afigura inconteste que a gravidez de feto anencéfalo deveria integrar o rol de normas permissivas do aborto.

A justificativa doutrinária se baseia no fato de não ser exigível da gestante prosseguir numa gravidez odiosa, que the acarreta sofrimento e que sempre lhe trará lembranças dolorosas. Prado (2008, p. 116-117) leciona que "o fundamento da indicação ética reside no conflito de interesses que se origina entre a vida do feto e a liberdade da mãe, especialmente as cargas emotivas, morais e sociais que derivam da gravidez e da maternidade".

Por sua vez, Dias (2006, p. 20) justifica de maneira diferente a razão de ser da excludente de ilicitude especial do aborto sentimental:

Mas não se pode esquecer que o Código Penal data do ano de 1940, época em que a sociedade estava de tal modo condicionada a preceitos conservadores de ordem religiosa, que outra não poderia ter sido a escolha do legislador. Não havia como deixar de prestigiar a paz familiar e admitir o aborto quando a gravidez resultasse da prática do crime de estupro. Tal exceção visa a permitir que não integre a família um "bastardo", pois a lei civil presume que o marido de uma mulher casada é o pai de seu filho. Assim, a gravidez, mesmo decorrente de violência sexual, faz com que o filho do estuprador seja reconhecido como filho do marido da vítima e herdeiro do patrimônio familiar.

Desta feita, em qualquer caso, há considerar que a vida humana, apesar de inviolável, não é bem absoluto, cedendo espaço a valores outros contemplados no ordenamento jurídico, como no caso do sofrimento psíquico causado por uma gravidez resultante de estupro. 
Não obstante, independentemente de qual seja a mens legis, se queria prestigiar a integridade moral da mãe ou então o patrimônio da família, um e outro justificaram a interrupção da gravidez quando esta decorre de violência sexual.

Assim, o mesmo raciocínio é passível de ser aplicado ao caso da gestação de feto anencéfalo, dado que o sofrimento de se ter que obrigatoriamente gerar um concepto que foi desejado, mas que é absolutamente inviável vem a ser tão equivalente ou até mesmo maior do que naquele primeiro caso, de gravidez fruto de delito contra a liberdade sexual.

Com efeito, numa gravidez voluntária o fruto da concepção fora, desde o início, desejado pelos progenitores que, em dado momento, já tendo criado fortes laços afetivos com o fruto de sua união sexual, descobrem que ele padece de uma grave enfermidade que the tolhe a viabilidade de vida.

Enfim, constatada a necessidade de se revisar a anacrônica legislação penal incriminadora do aborto, sobretudo no que concerne à gestação de feto portador de anencefalia, compatibilizando-a com a nova ordem constitucional, é mister vislumbrar as premissas que denotam a inconstitucionalidade daquele diploma legal, explicitando-se sua desproporcionalidade.

\section{A DESPROPORCIONALIDADE DA CRIMINALIZAÇÃO DO ABORTAMENTO DE FETO ANENCÉFALO}

A problemática da interrupção da gravidez, mormente da que abriga feto portador de anencefalia, incorpora um confronto entre direitos fundamentais, bens e valores constitucionalmente tutelados, tais como a vida - ou, em último caso, o interesse estatal em tutelar a expectativa de vida do nascituro -, a viabilidade desta, a liberdade da gestante e, consequentemente, sua privacidade, sua saúde e seus direitos reprodutivos.

Todos estes direitos e bens estão previstos, explícita ou implicitamente, na Constituição e, por isso, desfrutam de uma 
tutela jurídica especial, sendo considerados invioláveis. Isso não significa, porém, que sejam absolutos (OLIVEIRA, 2009, p. 29).

A própria coexistência de direitos de diversas dimensões pressupõe a limitação recíproca de cada um dos direitos, também chamada de convivência das liberdades públicas. Não bastasse, o exercício desses direitos por vários sujeitos de direitos também limita a esfera de proteção jurídica dos direitos de cada um.

Constatada a ausência de hierarquia, in abstrato, entre os direitos fundamentais, princípios e bens constitucionais, urge discorrer sobre os bens e direitos especificamente ligados à situação do abortamento de feto anencéfalo, cuja criminalização, ao depois, será submetida a um exame de ponderação para averiguação da sua constitucionalidade material.

De um lado, há o interesse estatal em proteger a vida do nascituro, uma vez que, de acordo com precedente da nossa Corte Constitucional - Ação Direta de Inconstitucionalidade 3.510 (BRASIL, 2008) -, o não nascido não é considerado sujeito de direitos assim como o é a pessoa nascida, já que a própria Constituição não teria feito "de todo e qualquer estágio da vida humana um autonomizado bem jurídico, mas da vida que já é própria de uma concreta pessoa, porque nativiva, e que a inviolabilidade de que trata seu art. 5\% diria respeito exclusivamente a um indivíduo já personalizado".

Em outros termos, ainda que não se considere o nascituro titular dos direitos fundamentais insertos na Constituição Federal, não há negar que o Estado tenha legítimo interesse em conferir à vida intrauterina alguma tutela jurídica. Todavia, é certo que no caso de gravidez de feto anencéfalo, por não desfrutar de viabilidade fetal, o interesse estatal de proteção à vida do nascituro diminui consideravelmente, isso se não for nulo.

De outro lado, figuram os direitos da gestante - liberdade, privacidade, direitos reprodutivos, direito à saúde etc. todos pautados pela dignidade da pessoa humana que, segundo 
Sarlet (2009, p. 67), é a "a qualidade intrínseca e distintiva reconhecida em cada ser humano que o faz merecedor do mesmo respeito e consideração por parte do Estado e da comunidade". O autor arremata explicando que ela implica em um complexo de direitos e deveres fundamentais que visa "propiciar e promover sua participação ativa e co-responsável nos destinos da própria existência e da vida em comunhão com os demais seres humanos, mediante o devido respeito aos demais seres que integram a rede da vida".

A liberdade consiste, na lição de Silva (2003, p. 232), na "possibilidade de coordenação consciente dos meios necessários à realização da felicidade pessoal”. A partir de tal conceituação, voltando-se para a hipótese de uma gravidez de feto anencéfalo, é possível afirmar que, a princípio, com base nessa cláusula, teria a gestante o direito de tomar as decisões importantes da própria vida, buscando sua própria felicidade.

No que tange à privacidade, esclarece Mendes (2009, p. 423) que, como proteção do indivíduo contra interferências infundadas em sua esfera íntima por parte do Estado, pode ser deduzida do princípio geral de liberdade, através do qual não se admitem "restrições à autonomia da vontade que não sejam necessárias para alguma finalidade de raiz constitucional". Destarte, com base no direito à privacidade é vedada qualquer atuação estatal inclinada a acarretar restrições no âmbito da vida privada das pessoas sem que aquelas sejam justificadas por um interesse estatal constitucionalmente legítimo para tanto.

Santos (2008, p. 45) salienta que o direito de escolha tem albergue nos direitos humanos e é ínsito ao regime democrático dos Estados contemporâneos:

O direito de escolha é uma das facetas dos direitos humanos e, no seu bojo, encontra-se o direito de decidir o prosseguimento de uma gravidez. A partir dessa ótica, Estados soberanos, potencializando a democracia dos seus cidadãos, permitiram que estes escolhessem os destinos do próprio corpo. 
Afastando as concepções religiosas, tais Estados perceberam que a maternidade passa, necessariamente, pelo direito dos interessados em aceitar ou não eventuais resultados biológicos do envolvimento sexual.

Nesse prisma, despontam os direitos reprodutivos como desdobramentos dos direitos à liberdade e à privacidade, cuja necessidade de garantia é ressaltada pela Convenção sobre a Eliminação de Todas as Formas de Discriminação contra a Mulher (ORGANIZAÇÃO DAS NAC̣ÕES UNIDAS, 1979), a Conferência Internacional sobre População e Desenvolvimento (ORGANIZAÇÃO DAS NAÇÕES UNIDAS, 1994) e a Conferência Internacional de Beijing (ORGANIZAÇÃO DAS NAÇÕES UNIDAS, IV Conferência Mundial sobre a Mulher, Desenvolvimento e Paz, 1995).

Os direitos sexuais, frise-se, integram a categoria de direitos fundamentais, por força da cláusula de abertura do art. $5^{\circ}, \S 2^{\circ}$, da Carta Política (BRASIL, 1988) e, por isso, devem ser respeitados e também viabilizados pelo Estado. Deste modo, tem a gestante o direito de decidir acerca da interrupção de gravidez de feto anencéfalo, pois se trata de uma decisão privada, atrelada aos seus direitos sexuais e reprodutivos.

Além disso, o abortamento de feto anencéfalo ainda se refere ao direito à saúde da gestante - garantia fundamental expressa nos artigos 6 e 196 da Constituição da República (BRASIL, 1988). Isto não só porque tal gestação acarreta mais riscos à saúde da mulher do que uma gravidez normal, chegando a ser considerada gravidez de risco, mas também porque a sanidade psíquica da gestante fica abalada por todo o sofrimento pelo qual passa alguém que sabe carregar em seu ventre um filho que foi querido e que já é amado, mas que irremediavelmente não logrará viver fora do útero materno.

Enfim, não se pode negar que o aduzido interesse estatal de proteção à vida do nascituro não se sobrepõe aos direitos da 
gestante, e nem estes excluem, de maneira absoluta, àquele. A harmonização de um e outros depende do juízo de proporcionalidade que a partir de então será realizado, a fim de se verificar a constitucionalidade material das normas penais que criminalizam o aborto, não ressalvando a hipótese de feto portador de anencefalia.

A análise da compatibilidade do teor dos citados tipos penais em relação à Constituição tem por parâmetro o princípio da proporcionalidade e seus princípios parciais (adequação, necessidade e proporcionalidade em sentido estrito).

Assim, em primeiro lugar, cabe verificar a adequação daquelas normas penais, primeiro elemento parcial da proporcionalidade em sentido amplo e que se refere à conformidade dos meios escolhidos pelo legislador em relação aos fins que ele busca.

Em se tratando o aborto de crime contra a vida, é forçoso admitir que, ainda que secundariamente, há um interesse em se proteger esse bem jurídico, ou então um interesse em garantir que a gravidez siga em frente para que culmine no nascimento com vida de uma pessoa, que se torna, então, sujeito de direitos.

Todavia, é inequívoca a premissa de que o feto anencéfalo praticamente não tem possibilidade de ter uma existência extrauterina e, quando a tem, ela não ultrapassa poucos dias de vida. Nesse sentido, elucida Vieira (2004, p. 32) quanto à certeza da aludida inviabilidade: "dada a gravidade das alterações morfológicas e fisiológicas do feto sem perspectiva de vida extra-uterina, esse erro é uma possibilidade remota”.

$\bigcirc$ tratamento criminalizante da interrupção da gravidez conferido pelo Código Penal, desde sua entrada em vigor em 1941, nunca foi capaz de coibir a realização de abortos ilegais. Além do que, citada proibição leva as gestantes a procurar meios clandestinos de interromper a gravidez, o que não raro resulta em graves danos à saúde e à vida dessas mulheres. Lapa e Gonçalves (2008, p. 261) coordenaram pesquisa sobre aborto 
nos tribunais brasileiros, cujas conclusões corroboram com a afirmação de ineficácia da legislação penal:

No período de seis anos estudados (2001-2006) foram encontrados apenas 130 acórdãos relativos a abortos clandestinos no país, enquanto que as estimativas desta prática chegam a apontar a ocorrência de cerca de um milhão de procedimentos ilegais por ano. (...) Ao que tudo indica, o caminho da penalização não tem sido efetivo em coibir a prática de abortos, sendo ainda responsável pela morte e comprometimento da fertilidade de milhares de mulheres.

Além disso, no caso específico de gravidez de feto anencéfalo, a proibição penal, mesmo quando observada, não é capaz de garantir a higidez da gestação, pois se trata de uma gravidez na qual já está embutida a própria ideia de aborto, em razão da inviabilidade do feto gestado. Fernandes (2007, p. 133-135) alerta que, nesses casos, não há falar em ofensa ao bem jurídico tutelado pelas citadas normas incriminadoras:

Através de uma primeira argumentação, conclui-se que inexiste afronta ao direito à vida, por se tratar de um ser "biologicamente vivo (porque feito de células e tecidos vivos), mas juridicamente morto", já que o conceito de morte adotado pela legislação brasileira - respaldado na literatura médica e no parecer do CFM sobre o assunto - não se restringe à cessação dos movimentos cardiorrespiratórios, incluindo a ausência de atividade cerebral. (...) Daí se depreende que afronta alguma haverá aos dispositivos penais ao se interromper a gravidez de feto acometido de anencefalia, já que a norma penal não abarca a proteção de um ser natimorto, cuja vida extra-uterina é absolutamente inviável, mas a de um feto considerado vivo pelos conceitos médicos.

Todos os argumentos até aqui expostos denotam a inadequação da lei penal ao alcance dos objetivos a que se propõe, e 
são suficientes para concluir a incompatibilidade daquela com a Constituição, por ofensa ao princípio da proporcionalidade. Todavia, a inconstitucionalidade ainda desponta da violação dos outros subprincípios.

A necessidade, segundo princípio parcial da proporcionalidade, exige que, dentre os meios aptos a atingir o fim pretendido, só pode ser adotado o que seja absolutamente imprescindível para sua obtenção, e ainda que afete o bem constitucional de maneira menos gravosa possível (STEINMETZ, 2001, p. 150-151).

No caso de interrupção de gravidez de feto anencéfalo, não é o abortamento necessário a garantir a integridade da suposta vida do nascituro - ou seja, a proibição do aborto não lhe devolve a viabilidade -, e sim é a antecipação terapêutica do parto a única medida necessária a garantir a amenização do sofrimento da gestante.

Assim, a criminalização do aborto em casos de gestação de feto anencéfalo não seria o meio necessário nem o menos oneroso para salvaguardar a viabilidade fetal. Nesse viés, Reis (1994, p. 281) afirma que: "o Estado não tem o direito de considerar criminosa uma mulher pelo fato de ela ter decidido interromper uma gravidez que não pode suportar, sobretudo um Estado que não oferece meios de contracepção e que possui um dos maiores índices de mortalidade infantil do mundo".

Efetivamente não é exigível que a gestante tenha imensurável sofrimento ao ser impedida de interromper a gravidez de um filho que sabe que não vingará, pois mesmo que nasça, terá ínfimas chances de sobrevida, e que será deveras precária, vegetativa.

Sarmento (2007, p. 48) aduz que a criminalização do aborto inflige sofrimento injustificado à mulher e viola princípios de estirpe constitucional:

Ora, um caso típico de legislação androcêntrica no Brasil é exatamente a que trata do aborto, elaborada sem nenhuma consideração em relação aos direitos e interesses femininos envolvidos. Ela viola 
a igualdade, na mesma medida em que gera um impacto desproporcional sobre as mulheres, já que as afeta com intensidade incomparavelmente maior do que em relação aos homens, de forma tendente a perpetuar a assimetria do poder entre os gêneros presente em nossa sociedade. Só a mulher, quando não se conforma com a legislação proibitiva e busca o aborto, se sujeita a graves riscos à sua vida e saúde, ao submeter-se a métodos quase sempre precários de interrupção da gravidez; só ela, quando obedece a contragosto a lei, acolhendo em seu ventre e depois gerando um filho que não desejava, vê seu corpo instrumentalizado e perde as rédeas do seu próprio destino.

Não há razoabilidade em um eventual interesse, socialmente falando, de se privilegiar o simples investimento biológico - no que concerne à aludida vida de um ser que está apenas biologicamente vivo, mas juridicamente morto e inútil, por não ostentar a menor possibilidade de se desenvolver e se transformar em uma pessoa consciente, um sujeito de direitos - em detrimento do investimento não só biológico, mas também humano - aqui numa referência à gestante, que indiscutivelmente é reconhecida como sujeito de direitos no nosso ordenamento jurídico, a qual vê tolhidos seus direitos ao não ser autorizada legalmente a interromper uma gravidez inviável, por gestar um emaranhado meramente biológico que não tem perspectiva nenhuma de vir a se tornar uma pessoa nascida, saudável e consciente de si, muito menos de ter uma vida plena e digna.

Fernandes (2007, p. 138) acusa a onerosidade que os tipos penais de aborto impõem à gestante, que se vê obrigada a prosseguir numa gravidez de feto anencéfalo:

O caso da gravidez de feto anencefálico guarda peculiaridades dramáticas, inexistentes no caso de uma gestação de feto viável, pois pode representar a dor de receber a triste notícia sobre a anomalia fetal, numa fase em que a gestante poderia estar fazendo 
planos sobre o nascimento do feto que só então saberá: não vai viver. Difícil também é imaginar o instante em que essa mulher, após ter esperado por nove meses um bebê, tiver que voltar para casa sem o seu filho. Mais triste ainda será o fato de ter que lhe dar um nome e sobrenome, apenas para constar do túmulo e do registro funerário de um ser que, paradoxalmente, chegou a existir apenas por alguns breves instantes após o parto.

O último componente do princípio da proporcionalidade alude à realização de um juízo de fina sintonia entre meios e fins utilizados, à luz dos bens e direitos constitucionais relacionados (STEINMETZ, 2001, p. 152), com o fito de conservar o equilíbrio entre eles.

Não respeita a proporcionalidade em sentido estrito exigir da gestante o sacrifício de prosseguir numa gravidez inicialmente desejada, mas que não tem, cientificamente falando, a menor condição de dar à luz um ser humano viável. Ora, tal coação significa a legitimação de uma forma de violência contra a mulher.

Ao sancionar penalmente a interrupção da gravidez de feto anencéfalo, o Estado nega às mulheres sua condição como titulares de direito, fechando os olhos para seus direitos reprodutivos, sua liberdade individual, sua privacidade, seu direito ao corpo e, sobretudo ao seu direito de exercer o planejamento familiar.

Como a proibição penal não é hábil a garantir a viabilidade fetal e igualmente não evita o sofrimento da gestante nem do feto anencéfalo, a melhor providência é aquela voltada a amenizar a dor da mãe (VIEIRA, 2004, p. 32). Isto porque, inadmitido o abortamento, a única saída à gestante é prosseguir na gravidez que não trará seu filho à luz, mas, inevitavelmente, a um sepulcro.

O Estado não pode obrigar uma mulher a continuar uma gravidez contra sua vontade, ainda mais uma gestação sobre a qual não há nenhum interesse estatal legítimo, como é o caso 
de uma gravidez cujo fruto não ostenta viabilidade fetal, pois isto obviamente lhe impõe imensuráveis fardos psicológicos e físicos, numa clara afronta aos princípios da privacidade e da igualdade (CHEMERINSKI, 2006, p. 821). Nesse sentido, Dworkin (2003, p. 143) conclui tratar-se de uma escravização parcial do corpo feminino.

Bitencourt (2008, p. 146) assevera que o aborto de feto anencéfalo é uma decisão tomada mediante reflexão e com base nas convicções íntimas da mulher:

Apenas, se preferir, a gestante poderá aguardar o curso natural do ciclo biológico, mas, em contrapartida, não será "condenada" a abrigar dentro de si um tormento que a aniquila, brutaliza, desumaniza e destrói emocional e psicologicamente, visto que, ao contrário de outras gestantes que se preparam para dar à luz a vida, regozijando-se com a beleza da repetição milenar da natureza, afogase na tristeza, no desgosto e na desilusão de ser condenada a - além da perda irreparável - continuar abrigando em seu ventre um ser inanimado, disforme e sem vida, aguardando o dia para, ao invés de brindar o nascimento do filho como todas as mães sonham, convidar os vizinhos para ajudá-la a enterrar um natimorto, que nunca teve chance alguma de nascer com vida.

Enfim, conjugando-se todos os argumentos colacionados até aqui, forçoso concluir que a integridade física e psíquica da gestante, sua liberdade, até quanto à escolha de colher os frutos da união sexual, são bens constitucionalmente albergados e que não podem ser violados para que se mantenha a gestação de um ser que não tem viabilidade extrauterina. Por conseguinte, é imperioso reconhecer a inconstitucionalidade material dos tipos incriminadores do aborto ao não excetuarem a interrupção da gravidez no caso de feto portador de anomalia incompatível com a vida extrauterina, ante sua já demonstrada desproporcionalidade. 


\section{CONCLUSÃO}

Os dispositivos penais que criminalizam a prática do abortamento e as normas permissivas que não contemplam a situação de gestação de feto anencéfalo devem ser interpretadas em consonância com a Constituição da República, fixando-se o sentido de que o aborto de feto anencéfalo não ofende o ordenamento jurídico-constitucional e, portanto, sua prática não pode ser considerada conduta antijurídica.

Isto porque a criminalização da interrupção da gravidez de um feto anencéfalo consubstancia-se numa restrição legislativa desproporcional aos direitos fundamentais da mulher gestante, como sua liberdade, privacidade, direitos reprodutivos e saúde.

A legislação penal que criminaliza a interrupção da gravidez é anacrônica. Em primeiro lugar, porque, à época da edição do Código Penal, em 1940, outros eram os valores fundantes da sociedade brasileira. Não só as relações entre as pessoas tinham regimentos diferenciados, como também a estrutura de poder era outra.

A partir da redemocratização do país e da Constituição de 1988, drásticas alterações foram ocasionadas na nossa estrutura política e social. Nesse cenário, os direitos humanos passaram a ocupar local de especial destaque no texto constitucional e, por conseguinte, o respeito e a implementação de direitos de tal estirpe tornou-se um imperativo inarredável à consecução dos objetivos de um Estado Democrático de Direito.

Nesse período de quase um século, sobretudo nas décadas mais recentes, a mulher, em nosso país, paulatinamente vê sendo reconhecida sua igualdade substancial. Todavia, a operacionalização da isonomia entre homens e mulheres só será completa ao se conferir a estas o pleno gozo de seus direitos reprodutivos, no exercício de um desdobramento do princípio-direito constitucional da liberdade.

Além disso, especificamente no que concerne à proibição de se interromper voluntariamente uma gravidez de feto portador de anencefalia, é indiscutivel a constatação de que no 
início da década de 40 do século passado a ciência médica não tinha se desenvolvido a ponto de permitir uma análise precisa da viabilidade fetal.

Atualmente, o quadro que se vislumbra é outro: o estágio avançado de evolução da medicina permite determinar com segurança a total inviabilidade do produto da concepção que venha a padecer de anencefalia fetal. Até porque, neste caso, o aborto espontâneo é o caminho natural da maioria das gestações ou, quando a gravidez logra chegar ao seu termo, o rebento não consegue viver por muitos dias fora do útero.

Nesse contexto, a verificação da constitucionalidade material da legislação penal incriminadora da interrupção da gravidez de feto anencéfalo exsurge como uma necessidade irretorquível, que visa à atualização e harmonização daquela legislação penal com os novos preceitos constitucionais, então vigentes.

No mister de realizar a verificação de constitucionalidade material de um ato legislativo, ficou assentado se tratar de uma atividade de ponderação entre direitos, bens e valores constitucionais envolvidos, instrumentalizada pelo princípio da proporcionalidade.

Destarte, cumpre efetuar um balanceamento entre, de um lado, o interesse estatal em tutelar as gestações, sobretudo as que atinjam certo grau de viabilidade, protegendo indiretamente a vida do nascituro, e, de outro, os direitos à liberdade, à privacidade, reprodutivos e à saúde da mulher grávida.

$\mathrm{Um}$ ato legislativo que restrinja direitos fundamentais só pode ser considerado constitucionalmente lídimo quando tem êxito no exame de proporcionalidade e de seus subprincípios: adequação, necessidade e proporcionalidade em sentido estrito.

Em síntese, será proporcional a medida legislativa que restringe direito fundamental, desde que seja não só adequada, mas absolutamente necessária a atingir o objetivo por ela colimado, de modo a adotar o meio menos gravoso possível ao 
alcance de tal escopo e, por fim, desde que o benefício por ela trazido seja maior ou igual ao ônus imposto, ou seja, que não seja exigível o sacrifício de um bem para a salvaguarda de outro.

O tratamento criminal conferido à interrupção da gravidez de feto anencéfalo não é adequado, por não ser meio apto a inibir a ocorrência de abortos, e porque não é capaz de garantir a higidez da gestação, muito menos de conferir viabilidade ao fruto da concepção.

Em se tratando de gravidez na qual já está embutida a própria ideia de aborto - pois o feto gestado, quando muito, não sobreviverá mais do que poucos dias fora do útero -, não se pode falar em vida extrauterina, mas sim em uma curta existência vegetativa de um ser que não se tornará sujeito de direitos, e nem uma pessoa consciente de sua dignidade.

Ademais, a criminalização também não é necessária, por não ser a forma menos gravosa dentre as possibilidades de tratamento jurídico do aborto de feto anencéfalo. Ao contrário, a proibição da antecipação terapêutica do parto só serve a ocasionar prejuízos à saúde das gestantes que se obrigam a realizar manobras abortivas clandestinas e inseguras.

A proibição do aborto não evita o padecimento de um ser que está fadado à morte prematura, não agracia o nascituro com a viabilidade. Ao contrário, é a antecipação terapêutica do parto a única e necessária medida para amenizar o sofrimento da gestante.

Não bastasse, os tipos penais de aborto não respeitam a proporcionalidade em sentido estrito, que reclama a realização de um juízo de racionalidade baseado no sopesamento dos meios e fins envolvidos, à luz dos bens constitucionais e direitos fundamentais em jogo. Assim, não é estritamente proporcional e fere a dignidade humana considerar criminosa a mulher que põe termo a uma gravidez que, embora desejada, não tem a possibilidade de trazer à luz seu filho, mas que o levará indelevelmente ao sepulcro. 
Ao exigir, por meio da proibição penal, o prosseguimento da gravidez de feto anencéfalo - gestação sobre o qual não há nenhum interesse estatal - o Estado impõe à mulher um ônus injustificado, negando-lhe o status de titular de direitos fundamentais. Referido atuar estatal tolhe do gênero feminino a possibilidade de fruição mínima de uma série de direitos constitucionalmente protegidos, sobretudo a liberdade, a privacidade, a autodeterminação, a saúde e os direitos reprodutivos.

A decisão de interromper a gravidez de feto anencéfalo deve ser tomada por cada mulher após muita reflexão e de acordo com suas convicções íntimas. Enfim, consubstancia-se em uma faculdade pertencente ao espectro de abrangência da liberdade, da privacidade e da autodeterminação de cada mulher, que não pode ser tolhida por uma imposição legal anacrônica e que passa ao largo dos valores constitucionais fundantes da sociedade brasileira do terceiro milênio.

Abstract: It is the purpose of this article to announce the dis proportion of the rules incriminating abortion in cases where the foetus has an anomaly incompatible with extra uterine life. It brings up the principle of proportion as an instrument to verify the unconstitutionality of rules. It highlights the anachronism of the criminal law typifying abortion and the disproportion of the criminalization of therapeutic anticipation of delivery in case of pregnancy with anencephalic foetus. The submission of criminal rules regarding abortion to an analysis in the light of partial elements of the principle of proportion - adequacy, necessity and strictus sense proportionality - leads to the final conclusion for the disproportion of the incriminating treatment of abortion when the pregnancy shelters anencephalic foetus.

Keywords: Abortion. Anencephaly. Collision of fundamental rights. Principle of proporcion. 


\section{REFERÊNCIAS}

ARAÚJO, Fábio Roque da Silva. O princípio da proporcionalidade aplicado ao direito penal: fundamentação constitucional da legitimidade e limitação do poder de punir. Revista dos Tribunais, São Paulo , v.98, n.882, p. 339-377, abr.2009.

BARROS, Suzana de Toledo. O Princípio da proporcionalidade e o controle de constitucionalidade das leis restritivas de direitos fundamentais. 3 ed. Brasília: Brasília Jurídica, 2003.

BARROSO, Luís Roberto. Os princípios da razoabilidade e da proporcionalidade no direito constitucional. Revista do Ministério Público do Estado do Rio de Janeiro, Rio de Janeiro, Procuradoria-Geral de Justiça, v.4, p. 160-175, jul. 1996.

BITENCOURT, Cezar Roberto. Tratado de direito penal: parte especial. 8 ed., rev. e atual. São Paulo: Saraiva, 2008. v. 2.

BRASIL. Constituição (1988). Constituição da República Federativa do Brasil. Disponível em <http://www.planalto.gov.br >. Acesso em 7/8/2009.

. Código Penal. Decreto-lei 2.848, de 7 de setembro de 1940.

Código Penal. Disponível em <http://www.planalto.gov.br〉. Acesso em $7 / 8 / 2009$.

, Decreto no 4.377, de 13 de setembro de 2002. Disponível em <http://www.planalto.gov.br/ccivil_03/decreto/2002/D4377.htm>, acesso em $5 / 9 / 2009$.

, Supremo Tribunal Federal, Ação Direta de Inconstitucionalidade 3.510, rel. Min. Carlos Ayres Britto, j. em 28 e 29/5/2008, Informativo 508. Disponível em <www.stf.jus.br>. Acesso em 3/8/2009.

, Supremo Tribunal Federal, ADPF 54, Rel. Min. Marco Aurélio de Mello, pendente de julgamento. Disponível em 〈www.stf.jus.br〉. Acesso em 3/8/2009.

BRANCO, Paulo Gustavo Gonet; COELHO, Inocêncio Mártires; MENDES, Gilmar Ferreira. Curso de direito constitucional. 4 ed. rev. e atual. São Paulo: Saraiva, 2009.

CANOTILHO, José Joaquim Gomes. Direito constitucional e teoria da constituição. 3 ed. Coimbra: Livraria Almedina, 1999. 
CERNICCHIARO, Luiz Vicente. Interrupção da gravidez e o anteprojeto de reforma do Código Penal. Revista jurídica Consulex, Brasília, v.174, p. 27, abr. 2004.

CHEMERINSKY, Erwin. Constitutional Law: principles and policies. 3. ed. Nova Iorque: Aspen Publishers, 2006.

DELMANTO, Celso et al. Código penal comentado. 6 ed. atual. e ampl. Rio de Janeiro: Renovar, 2002.

DIAS, Maria Berenice. Direito fundamental ao aborto. Revista Magister de Direito Penal e Processual Penal, Porto Alegre, Magister, v.11, p. 20-21, abr. 2006.

DILGUERIAN, Mirian Gonçalves. Princípio constitucional da proporcionalidade e sua implicação no direito penal. Revista de direito constitucional e internacional, São Paulo, RT v.43, abr. 2003, p. 168-208.

DOBROWOLSKI, Silvio. Direitos fundamentais: a cláusula de expansão do artigo $5^{\circ}$, parágrafo $2^{\circ}$, da Constituição de 1988. Revista do Tribunal Regional Federal 4. Região. Porto Alegre, v. 17. n. 61, p. 45-85, 2006.

DWORKIN, Ronald. Domínio da vida: aborto, eutanásia e liberdades individuais. São Paulo: Martins Fontes, 2003.

FERNANDES, Maira Costa. Interrupção de gravidez de feto anencéfalo: Uma análise constitucional. In: PIOVESAN, Flávia; SARMENTO, Daniel (coords.). Nos limites da vida: aborto, clonagem humana e eutanásia sob a perspectiva dos direitos humanos. Rio de Janeiro: Lumen Juris, 2007. p. 133-135.

GONÇALVES, Tamara Amoroso; LAPA, Thaís de Souza (Coord.) Aborto e religião nos tribunais brasileiros. São Paulo: IPÊ, 2008.

GUERRA FILHO, Willis Santiago. Sobre princípios constitucionais gerais: isonomia e proporcionalidade. Revista dos Tribunais, São Paulo, RT v.719, p. 57-63, set. 1995.

MIRABETE, Júlio Fabbrini. Manual de direito penal: parte especial. 6 ed. rev. e ampl. São Paulo: Atlas, 1991.v. 2.

NACIONES UNIDAS. Informe de la Cuarta Conferencia Mundial sobre la Mujer. Disponível em <http://www.un.org/womenwatch/daw/beijing/ pdf/Beijing\%20full\%20report\%20S.pdf>, acesso em 8/9/2009. 
NORONHA, E. Magalhães. Direito penal: dos crimes contra a pessoa; dos crimes contra o patrimônio. 29 ed. atual. São Paulo: Saraiva, 1998. v. 2.

NUCCI, Guilherme de Souza. Manual de direito penal: parte geral: parte especial. 3 ed. rev., atual. e ampl. São Paulo: Editora Revista dos Tribunais, 2007.

OLIVEIRA, Regis Fernandes de. Descriminação do aborto: uma visão jurídica. Revista jurídica Consulex, Brasília , v.13, n.293, p. 28-31, mar.2009.

SARMENTO, Daniel Antonio de Moraes. Legalização do aborto e Constituição. In: PIOVESAN, Flávia; SARMENTO, Daniel (coords.). Nos limites da vida: aborto, clonagem humana e eutanásia sob a perspectiva dos direitos humanos. Rio de Janeiro: Lumen Juris, 2007. p. 3-51.

PRADO, Luiz Régis. Curso de direito penal brasileiro: parte especial. 7 ed. rev., atual. e ampl. São Paulo: Editora Revista dos Tribunais, 2008. v. 2.

REIS, Dagma Paulino dos. Aborto: a polêmica interrupção voluntária ou necessária da gravidez. Uma questão criminal ou de saúde pública? Revista dos Tribunais, São Paulo, RT v.709, nov. 1994, p. 277-284.

SAMPAIO, Patrícia Regina Pinheiro; SOUZA, Carlos Affonso Pereira de. O princípio da razoabilidade e o princípio da proporcionalidade: uma abordagem constitucional. Revista Forense, Rio de Janeiro, Forense, v. 349, p. 29-41, jan. 2000 .

SANTOS, Jeifson Ribeiro dos. Legalização do aborto: pela efetivação do direito natural à liberdade de escolha. Revista jurídica Consulex, Brasília, v.12, n.273, p.42-47, maio 2008 .

SARLET, Ingo Wolfgang. Dignidade da pessoa humana e direitos fundamentais na Constituição Federal de 1988. 7 ed. rev. e ampl. Porto Alegre: Livraria do Advogado Ed., 2009.

STEINMETZ, Wilson Antônio. Colisão de direitos fundamentais e princípio da proporcionalidade. Porto Alegre: Livraria do Advogado, 2001.

UNITED NATIONS. Tradução não oficial do "Summary of the Programme of Action of the International Conference on Population and Development". Disponível em <http://www.unfpa.org.br/Arquivos/ conferencia.pdf >, acesso em 8/9/2009. 
230 | CAROLINE KöHLER TEXERRA

VIEIRA, Tereza Rodrigues. Aborto por anomalia fetal e o direito atual. Revista Jurídica Consulex, Brasília, v 8, 174, p. 32-33, abr. 2004

WAMBIER, Teresa Arruda Alvim. Aborto: feto com má formação congênita: anencefalia. Revista jurídica Consulex, Brasília, v. 174, p. 24-33, abr. 2004 . 